\title{
SCIENCE FOR MODERN LIVING*
}

\section{E. EUGENE IRISH \\ Lecturer in Education, University of Michigan, Ann Arbor, Mich.}

I rather imagine there are nearly as many misconceptions of science as there are of education. I have a strong feeling that most people have a superstitious regard of science as some giant bogey-man inhabiting astral space somewhere, or else a peculiar, conspiring, personally known group of individuals who constitute the great power known as science.

Science is a very amorphous thing. It's very difficult to define it and to describe it. The best dictionaries have a great deal of difficulty, for they must include meanings that are widely different. Science does not consist of Einstein, Millikan, Eddington and great people of that type. Science is going on all around us-in the classroom; in conferences, such as this; in some of our large manufacturing companies; among the technicians in the laboratories of our hospitals; and among the nurses and good doctors in all the offices throughout this country; wherever an engineer is working in a plant, or over his drafting board. Even in our social study groups there are scientists at work-scientists in the management of cities and in the nature of city living. These people are scientists. But, when we talk of the great and awful science that is about to destroy us with its blind inventions, we somehow or other forget that most of us, or a good many of us, belong to the field of the scientists; that it's our sons or our brothers and sisters who are the scientists.

How would you describe and define science? Certainly not by the subject matter. Here are just a few of the areas of science--just a few of them listed: there's pure science, abstract science, concrete science, experimental science, physical science, moral science, mathematical science, historical science, science of government. How many more would you include? All of these are sciences.

Certainly, then, it's not to be distinguished by its subject matter, for there is a great difference between the science of astronomy and biological science. There is a great difference between the chemist in the laboratory of a commercial institution and the historical scientist. There is a great difference between the political scientist and the technician who checks your blood when you enter the hospital. And, yet, all of these people are scientists, and they're all governed by the term "science."

Nor is science to be distinguished by the kind of people engaged in it. Because Eddington, Einstein, and the like, are great, famous

\footnotetext{
* An address delivered September 5, 1952 at the Johnson County Teachers' Institute, Kansas City, Kansas.
} 
figures, doesn't change them in quality or character or type from this almost totally unknown person who is so vital to you and your health - this laboratory technician. Science includes as many different kinds of people as there are kinds of people. Within any one branch, such as the biological sciences, you will find a complete spread of all the different types you can imagine. Then, what is science, what does it cover, and who are the scientists? This is important for an understanding of the problem and for clarity of our thinking, lest we blame "the scientists" and not know who the scientists really are.

Science is distinguished by a method of procedure called the scientific method, and wherever that method is used, science exists. Wherever an individual is accustomed to using the scientific method in his work, he is a scientist. This scientific method consists of such things as observation of the world or of the particular segment that you isolate for your own purposes; the formulation of hypotheses as to what you expect will happen if you do certain things, hypotheses which arise as a result of observation or curiosity about things or ideas; and then, the experimental testing of these hypotheses, or hunches, as to what will happen. You actually test the situation to see what will happen. And then, you get something which you tentatively identify as knowledge - information, facts, concerning this field of your investigation. You have an experimental truth which you hold out for anyone to test for himself--either to confirm or to change or to deny; on the basis, again, of observation, hypothesis, experimentation, and testing. This is what distinguishes all scientific effort-all scientific effort.

Science is distinguished in the second place by the fact that it attempts to correlate all of the knowledge that the individual scientists accumulate. Science must write laws within the individual field, laws which will cover the various results which the scientists have found to be true. As these results come in, they're classified and categorized and laws are written about them-descriptive laws, which are ways simply of telling you in general what will happen under these given circumstances. And you know that these results will always occur whenever these conditions are presented. Science, then, is a method of procedure, and it's a type of "knowledge." I put knowledge in quotes there, because we're reaching the stage where we will assert that only such things as come to us through the scientific method, or only such things as are tested by the scientific method, will we include within the realm of the term "knowledge." So, science gives us this particular, tested, confirmable type of knowledge. And wherever we have that kind of information, that kind of knowledge, we have science. 
What are the objectives of science? They're very simple, I think. Although, they're worth a great deal of consideration as to the results of such simple objectives.

The first, is to find the truth - just to find the truth. The scientist is one who wants the truth. If he is concerned with education, he wants to learn everything he can about this broad field-every aspect of it. If he is studying flood-control, he wants to know as much as is possible about the causes as well as the effects of devastating floodwaters. If he is an anthropological scientist, he wants the story of what took place in the history of the development of this thing called human life. If he is a biological scientist, he wants the truth, nothing but the truth, of the physical organism and what the rules are which will best lead to the development of this thing that we call humanity, and what the truths are which we can find in the lower levels, and whether there is anything running through all of these forms of life whether there is any truth to be revealed here that would tie them all together. Regardless of what it is, whether it hurts, whether it helps, whether we like it, whether we don't like it, whether it means our destruction or whether it means our salvation, the scientist's job is to find the truth.

The second objective is to formulate laws - to relate these truths so that one has meaning and relevance for another. Those are all the objectives of science, as I see it.

Now, what are some of the values of science?

First of all, as I've indicated, we should have it clear in our minds that this is by all odds the most successful method of getting truth. In some ways it's strange to put it that way, for sooner or later we'll know that this is the only way to get truth. But at this stage, it's by all odds the best way of getting truth. No other method, whether you want to call it inspiration, revelation, intuition, hunch, emotion, or what have you, can produce truth in the way that the scientific method does. That's important, isn't it, for every area of our lifenot merely for those men who are working with atoms and molecules; not merely for those people who are studying blood types, and analyzing the story that the blood cell has to tell. But, it's important for the conduct of our government; it's important for the conduct of our educational institutions that we have scientists designed to study education, or the relationships of knowledge to children and adults, in the same way that we have people studying the importance of certain alloys for certain uses. It's important that science, this understanding of it, become a part of our home life, our living together, so that we don't depend in this very important area of our existence on hunches and intuitions which may be very wrong. Slow accumula- 
tions of ideas or attitudes untested, uncritically accepted, may be very destructive. If scientific method produces the greatest truth and advance and progress in production, in our understanding of history, in our understanding of ourselves, and in the elimination of disease; isn't it time that scientific method become a part of our home life, and of our educational life, and of our social and political life? This is a great value of science.

Secondly, science eliminates the personal. I believe this is its greatest contribution and its greatest value. It eliminates the personal! This is so difficult to do that we may succeed in it in the particular area where we are trained to be scientific, and be completely oblivious of the rules and the values, when we move out into any other area. This is what is at fault, I think, with a good many scientists-that they have not really accepted their own methods. They use them in their own particular fields. One scientist will use it in his field, and move over into another area of scientific effort and proceed as the savage who never heard of the method of testable knowledge and the elimination of the personal. I know that it's the greatest thing we have to overcome for the establishment or growth of community-to eliminate the personal. It seems at this stage almost impossible. We reject an idea because we don't like it. We refuse to listen any longer, when we hear an idea that hurts us. I try to fashion my teaching on this proposition, and I am most often critized for my failure to do it. People say to me: "You make that statement at the beginning of your lecture, and you'll lose half your class right there. They'll go on sitting, but they will not be listening." And half is a conservative estimate. We don't like certain things, and when we run into those things we don't like we refuse to pursue the investigation any further. We'll build walls. We do this with each other in our families. We do it in our educational communities, and we certainly do it in our civic and business associations.

Science says, "Your personal taste, your personal interest, the thing you like or don't like, has nothing whatsoever to do with this investigation. You will be a good scientist only insofar as you succeed in completely transcending your personal desires. Unless you do it, you're no good in any scientific effort." And isn't it becoming clear that unless we can do this, unless we can achieve this end, we are no good in any human effort? Science has set the ideal, it's established the goal. It's a great objective, it's a new thing. Science not only has said, "This is something to achieve." It has established the method for achieving it! Follow the method and you will come out in the end with the right answers. We can learn from this; we should learn from this. We have to learn from this scientific value. 
In the third place, science is cooperative and universal in its nature. It's impersonal, too, in its nature. For not only does the scientist exclude his personal feelings from his investigation, but it doesn't matter who does the work. It doen't matter whether he's a Greek: or a German, a Negro or a Caucasian - as long as he does his work. Do you realize there are no lines drawn in science? Great scientists, social and physical, have been Negroes. No one questions the results of their work because they're Negroes. We had got around to having little or no respect for the Italian people, but an Italian helped produce the atomic bomb. We're glad to share with the Germans our scientific knowledge and to take all that they've got to offer. And so with the Japanese. It's as though we were lifted up into an impersonal realm where all the littleness of our human reactions and of our bitterness and of our pride and prejudice were dropped away and we were actually living in a world where a man counted for what he was and for what he could do, not because of any other consideration. This is a tremendous achievement. If we could only take that vision and bring it down into our other life! Even the scientist doesn't do that. He will live this way and think this way in his science. But when he moves out of his science he becomes like the rest of us.

It's this impersonality which provides the cooperation, and it's international. Scientists have gone way out beyond the borders of country and nation and class and color. They cooperate with each other. Men who have never seen one another are the closest of friends through their scientific interchange. When a scientist discovers something, unless he happens to be working for himself in a particularly lush sort of commercial way, it's put on the market and he says: "Here's what I've learned. What have you learned?" The American says to the person way over in Australia or India: "This is my observation. Will you test it for me, will you check it, will you let me know whether I'm right or wrong, whether you agree or disagree?" And that goes on all over the world-cooperation-international and impersonal. This is a marvelous achievement, far more valuable than any single invention the scientists have made, far more valuable than any collection of inventions. For, if we have the method, we'll go on inventing from here on; but if we don't have the method, we're lost. Throw out every invention we have; keep the method and the attitude and the desire, and we'll build a new world.

Now, what are some of the failures of science? We have been dealing with some of them as we've gone along - cross references. First of all, its materialism. Science has been very materialistic. There was no necessity for it. Oh, there was an inclination toward it, insofar as the scientific method works best with precise, measurable quantities 
that you can isolate in test tubes and cyclotrons, and so on. But there was no necessity for this materialism. And then, there was a great pride in the fact that we were learning so much about our world and about ourselves, that now we were getting more and more power, and this power was all in the material world that we were taking apart. And so then, the scientists began to think there was nothing else but this power which they were discovering and controlling. And seeing no purpose, seeing no vision, having no understanding of any of the other fields of possible scientific effort, they said, "Matter is all." They've gone on that basis until now; until here it is: it's purely a matter of the physical.

This is particularly due to the second evil of over-specialization. We've got to have specialists. We've got to have people in the community to whom we can say, "Go away from us for a while and study this thing." We've got to have people who will take one field and make it theirs and become expert in that field.

But this specialization has led to a kind of isolationism, which is a direct contradiction of the basic nature of science as a cooperative effort. The very nature of science has driven it into an error, which is a violation of its own principle. It happens in more than the field of science-this insularity of men who possess amazing knowledge in some small field, and know almost nothing of what goes on all around them. I'm not sure that the modern world with its terrible interconnectedness has room for people who don't realize the interconnectedness. There was a time when we could afiord to let people like that go on. I'm not so sure we can any longer. It seems to me that's an evil.

In the third place is the scientist's lack of social concern. His materialistic inclination and his isolation in a particular area, have both contributed to his lack of social concern. He's been a little scornful of those of us who were not scientific and who didn't have exact data to work on. He's a little scornful of those who can't weigh things and measure them. Then, too, I think he's a little afraid when he gets out into this larger area of human life; for he's safest when he's got the things he knows and the things he can handle about him. Have you noticed how many of these scientists and scholars of this type are so socially immature and so frightened and fearful when they get into groups? There's some meaning in that and some reason for it; for the skills that are necessary for social living are skills that are just as difficult, if not more difficult, to achieve than the skills required for any scientific effort.

This lack of social concern goes on all the way down from some of the big people, who say they don't care whether these things they are 
working on are of any value to anybody, to the doctors and the engineers and the technicians, and even the social service workers and historical scientists, who have little or no concern for this great experiment of living together. And how much of an active part do these technical scientists play in the welfare of the government, outside of the contribution they make in their own particular fields of effort? Most of these people will justify their abstention; not merely say that it's not true that they abstain. They justify their abstention! And that, I suppose, is the greater wickedness-or maybe it isn't.

But I am appalled by the lack of social concern of our technical and professional people. Our cities are not being run by such people. Our city affairs are not receiving the benefit and the vision of these people. They are not receiving the result of their scientific training and of the enormous amount of educational effort that's gone into producing them. I'm sure the churches aren't receiving it, and I'm just as sure that it isn't going into our social well-being on a city, state or national level. Isn't that important? That our best-trained people, the people who are trained to find the facts, the people whose objective it is and whose basic principle of operation is impersonalityisn't it significant that these people don't seem to care about how we live together?

The atomic scientists, because of one more door opening which scared even them, are now the ones who are most active in the field of social concern. Maybe the others will come along. Let's hope so. But to all the doctors who are worrying about socialized medicineand that means, as far as I can determine, all the doctors - there's a warning in the behavioral pattern of the atomic scientists that maybe they had better begin to become concerned with how people live and with what people need and with what people want; so that in some of our cities where there's corruption destroying the health of our people, the doctors will speak out for a change, and not be afraid of their professional honor and of the things that the rest of the members of - their profession-will say. And the engineerswherever there are scientists-they've got to begin to realize that there are people like ourselves who are concerned with the way in which we live together. We need more facts and we need more dedication to the problems of living together.

I've been implying throughout the importance of interdependence, brotherhood, and social life. Every last scientist has been producing evidence, which indicates this interdependence. This is not something that a deeply religious person gets in a revelation. This point of interdependence has been presented to us by the scientists-by scientists in every field. We are interdependent and we cannot escape 
it. The biological scientist has been demonstrating our brotherhood, the fact that we belong to each other and that we are all brothers. And the social scientist has been pointing out, as has the anthropologist and the biologist, that we've got to live together in a community; and that from the beginning of life, for instance, there's been a growth of this thing we call our altruism-our concern for the whole even at the expense of ourselves - and that cooperation is a fundamental rule of evolutionary development. Interconnectedness, brotherhood, and social life- these three things science notes, science establishes.

The future of this relationship of science to the problems of day-in and day-out living is one that everyone must face. We must first of all realize that we must be scientific. We are the ones who must be the scientists. Your job may be routine, but there is a place in which you can be scientific, and that's in the acceptance or rejection of things that other people who are trained to produce knowledge or facts present before you. You can be scientific in the way you understand your school and your community; you can be scientific in the way you live in your family; and you can be scientific in your teaching. All of these areas are open for you.

We ought to know by now that facts alone will not solve our problems. And yet, it seems to me that the greatest error into which most of us as teachers fall, is in assuming that simply because something is learned, desirable behavior with respect to it follows. To put it another way, mere knowledge of a particular referent does not always preclude favorable behavior with respect to it. I'm using the word "referent" in this case to denote anything-an object, a person, a group of persons, an idea. Many of us know, for example, that eating certain foods is not good for us. We know that. We know it to be a fact. Yet, many of us continue to eat those very foods.

If education is concerned with producing desirable changes in behavior, then perhaps we should ask ourselves this question: "How do you get people to want to do the things you want them to do?" How is acceptance of an idea or an attitude effected-acceptance, that is, with understanding?

I realize there are many teachers who sincerely believe that learning is taking place, whenever their pupils have discharged some routine assignment, or whenever they have managed to demonstrate a reasonable competency in some skill. In fact, I know a teacher who prides himself on the basis that he, " . . makes 'em learn." Now, nobody ever made anyone else learn anything. You may think that learning is taking place under such circumstances, but actually it isn't. Strange, isn't it, that the same teacher who says, "I make 'em learn," turns right around and says, "I don't understand why my 
pupils forget so much." The chances are that what the teacher thought was learning was so obnoxious to his pupils that they couldn't forget it fast enough -if, indeed, they ever did learn it. So once again, I pose the question: "How do you get people to want to do the things that you want them to do?" This is especially important to those of us who are charged with the responsibility of training children.

Assuming that we know what's desirable in the form of a curriculum or program of studies, and assuming that we know what's desirable in the way of attitudes and skills and behavior, how do we get our students to the point where they will feel that such things are important and desirable, and that they, too, will want to achieve them? It isn't an easy question to answer, nor is there any one answer that can be made applicable in all cases. The problem simply defies any easy generalization that might cover all situations. But this much we do have; this much we know: science has shown us the way; science has given us the procedure; science has established the method. It's up to us to instill the desire and to inculcate the attitudes.

\section{FOURTH EDITION OF RADIO OPERATOR'S LICENSE Q\&A MANUAL}

John F. Rider Publisher, Inc., 480 Canal St., New York 13, N. Y., announces that the Fourth edition of "Radio Operator's License Q\&A Manual," by Milton Kaufman was published in December.

The new edition is in complete accordance with the FCC Study Guide now being used as a basis for radio license examinations. The text has been brought up-to-the-minute, particularly with regard to new operating procedures and new frequencies. Questions which have become obsolete since the last edition have been deleted. Questions have been renumbered to make them conform to the latest Study Guide. Discussions to many questions have been amplified so that the reader may achieve maximum background information.

The method of presentation is clear, logical and completely easy to read. Questions follow those presented in the current FCC Study Guide for radio operator's license exams; the answers are given in a wholly understandable way, followed by simplified discussions of the topics. It is this discussion feature of the book that enables the reader to acquire a more thorough explanation of the question. All eight Elements, which include Element 7 on Aircraft Radiotelegraph and EJement 8 on Ship Radar Techniques, are covered fully in this same method.

The volume offers valuable appendices on Small Vessel Direction Finders and Automatic Alarm, which are exclusive with this book.

Primarily designed as a study aid, the book covers all the information necessary for the successful completion of the FCC examinations for radio operators. As a reference volume, it offers a quick, easy-to-locate review of essential theory. The new "back-pressure arm-lift" artificial respiration method is discussed with illustrations. The subject matter is given according to Element, in the same manner as presented on the FCC exams. However, if the reader wishes to study by subject, rather than by Element, the thoroughly complete index enables this procedure to be followed with maximum convenience.

"Radio Operator's License Q\&A Manual," Fourth Edition, contains 730 pages in a cloth binding. Profusely illustrated, it is $5 \frac{1}{2}{ }^{\prime \prime} \times 8 \frac{1}{2}{ }^{\prime \prime}$ in size. It is priced at $\$ 6.60$. 